\title{
Social Responsibility Accounting And Profitability of Dangote Cement PLC Listed in the NSE
}

\author{
Lyndon M. Etale \\ Department of Accounting, Faculty of Management Sciences \\ Niger Delta University, Wilberforce Island, Bayelsa State, Nigeria \\ Ayaundu E. Sawyerr \\ Department of Accounting, Faculty of Management Sciences \\ Niger Delta University, Wilberforce Island, Bayelsa State, Nigeria
}

\begin{abstract}
This study examined the relationship between social responsibility accounting and profitability using Dangote Cement PLC (DCP) as a case study. The study adopted staff training and development, staff welfare and healthcare cost, and staff pension and gratuity as proxy for social responsibility accounting (the explanatory variables), while profit after tax representing profitability was adopted as the response variable. Secondary data was collected from the annual financial statements of DCP for the period 2010 to 2018. The study employed descriptive statistics and multiple regression analysis based on the E-view 10 software for data analysis. The results revealed that staff training and development, and staff welfare and healthcare cost had significant positive relationship with profit after tax, while staff pension and gratuity had an insignificant negative link with profit after tax. The coefficient of determination (R-squared) value of 0.99 indicated that $\mathbf{9 9 \%}$ of changes in the response variable are accounted for by the combined effect of changes in the explanatory variables; and results are statistically significant with a probability of F-statistic value of $\mathbf{0 . 0 0 0 0 0 0}$ (at 5\% level of significance). Also, the adjusted R- squared value of 0.99 indicated that the model used for the analysis is a proper and good fit. The study concluded that social responsibility accounting is significantly related to profitability. Based on the findings of this study it is recommended that the management of DCP should continue with the social responsibility accounting practices for its good social image as this would guarantee the long run sustainable growth of the company.
\end{abstract}

Keywords: Gratuity, Profitability, Social responsibility accounting, Staff welfare, Training

\section{INTRODUCTION}

Social responsibility reporting refers to the measurement and communication of information about a company's impact on employee welfare, the local community and the environment. The philosophy behind the measurement of a corporate entity's social profits or social performance can be likened to a popular saying what gets measured, gets managed. Social responsibility reporting is 
Etale, L. M., \& Sawyerr, A. E. (2020) Social Responsibility Accounting And Profitability Of Dangote Cement PLC Listed in the NSE. Advances in Social Sciences Research Journal, 7(5) 323-337.

a way to demonstrate corporate citizenship. The intent of social responsibility initiates is to deliver positive outcomes for all stakeholders in the business that results in long term sustainability which integrate economic, social and environmental performance referred to as triple bottom line reporting otherwise interpreted as profits, people and plant (Wilson, \& Lombardi, 2001). This is anchored on the triple bottom line (TBL) accounting framework pioneered by Elkington (1997) which require that business entities report performance in three parts: financial performance, social performance and environmental performance.

This study addressed the aspect of corporate social responsibility (CSR) that deals with people (social performance) in essence the employees of a company. According to Susan Cooney head of global diversity, equity and inclusion at Symantec, customers are not the only ones who are drawn to businesses that give back, hence a company sustainability strategy is a big factor in where today's top talent choose to work. The next generation of employees would be looking out for employers that would be focused on the triple bottom line approach to handling business affairs. One way a company can practice good social behavior in relation to people (human resource) is by instituting ethical labor practices. Companies that are committed to social performance would treat employees in an ethical and fair manner with equitable compensation and experience reduction in labor turnover rate as well enjoy sustainable success (Atu, 2013). By treating employees fairly and ethically companies can demonstrate their social responsibility.

Several researches have been carried out on corporate social responsibility with divergent and mix results across continents; while most researchers addressed social responsibility accounting (SRA) as a broad term this study seeks to demonstrate the materiality to financial performance of human capital reporting which only a few researchers have delved into. Despite the surge in technological advancement the way human capital is managed, developed and promoted is likely to be one of the key determinants to long term business sustainability.

More than ever quoted companies in the Nigerian Stock Exchange whose activities impact on the environment are working hard to protect their reputation and the environment in which they do business. Most companies are more concerned with external CSR issues (profit and planet) as these have an expository effect on their negative practice thereby neglecting the internal SRA issues (their employees representing people). There internal SRA involves social responsibility practices for employees especially in the area of their safety, health and wellbeing, training and participation in the business equality of opportunities and work life balance (Vives, 2006). Most quoted oil companies carry out internal CSR activities as its affects employees but a lot of inconsistency has been observed in internal CSR activities in consecutive years thereby questioning the relationship between SRA and profitability of these quoted oil Companies. Also, Chepkwony, Kemboi and Matai (2015) wondered as important as corporate social responsibility is, banks in Kenya have neglected it and internal CSR does not appear to have the desired impact on all employees as expected by the management.

Though the multinationals, foreign governments and international NGOs have been the primary drivers of social responsibility accounting but their Nigerian counterparts are yet to fully embrace the concept (Helg 2007). NGOs are perceived to have played a key role in the introduction and development of CSR and most companies recognize them to be one of their primary stakeholders (Arenas, Lozano \& Albareda, 2009). Ohaka and Ogaluzor, (2018) noted that in Nigeria some 
companies practice corporate social responsibility without disclosing it in their financial statements while others do not practice it. They observed the need for in-depth study into the quality, extent of corporate social responsibility (CSR) disclosure and identification of areas for future improvement so that transparency can be ensured especially in developing countries like Nigeria where CSR practices are limited.

Dangote Cement PLC (DCP) manufactures and distributes cement and related products for the limestone mining, coal production and property investment industry in Nigeria and the rest of Africa. The company is Sub-Saharan Africa's leading cement company with operations in 10 countries - Cameroon, Congo, Ethiopia, Ghana, Nigeria, Senegal, Sierra Leone, South Africa, Tanzania and Zambia. It has a production capacity of 45.6 million tons per year for the 10 countries, and integrated factories in 7 countries, a clinker grinding plant in Cameroon, and imports and distribution facilities for bulk cement in Ghana and Sierra Leone. DCP is building sustainable business for the benefit of all stakeholders. In terms of job and wealth creation, DCP had 18,312 direct employees and an additional 7,969 third party contractors in all its locations as at 2018, creating 29.6 billion, 32 billion and 11.1 billion naira respectively in household income, indirect and induced impact in wealth for associates. The company has a strong commitment to staff development through its training academy with extensive programmes, and working with local communities to provide jobs and services and other benefits like housing, water and healthcare. In the same year 2018, over 11,000 employees received training in different courses, and 972 students in different universities benefited from the Dangote scholarship scheme. Formerly known as Obajana Cement PLC, the company which is subsidiary of Dangote Industries Limited with head office in Lagos, Nigeria changed its name to Dangote Cement PLC in 2010, and as at April 2020 the company's market price was 130 naira per share with a market capitalization of over 2.2 trillion naira.

It is against this backdrop that this research work is being carried out with the intent of centering in on SRA as it affects employee, and to establish the link between internal SRA and profitability using DCP as a case study. The study therefore examined the link between social responsibility accounting and profitability using available data from DCP on internal SRA components such staff training and development cost, staff welfare and healthcare cost and staff pension and gratuity as explanatory variables, while profit after tax (proxy for profitability) as response variable.

This article is structured into five parts. Part one above covers the background introduction following in part two is the review of related literature. Part three deals with the methodology adopted in carrying out the study, while the results of data analysis and discussion of the findings are covered in part four. Finally the summary, conclusion and recommendations of the study are presented in part five.

\section{Conceptual Clarification}

\section{REVIEW OF RELATED LITERATURE}

\section{Corporate Social Responsibility (CSR) and Social Responsibility Accounting (SRA)}

Business is a socio-economic activity and it draws its inputs from the society, hence its objective should be the welfare of the society. Accordingly, the World Bank Institute (2003) defined CSR as the commitment of business to contribute to sustainable economic development, working with employees, the local community and society at large to improve their quality of life. It should owe a 
Etale, L. M., \& Sawyerr, A. E. (2020) Social Responsibility Accounting And Profitability Of Dangote Cement PLC Listed in the NSE. Advances in Social Sciences Research Journal, 7(5) 323-337.

responsibility towards solving many of the social problems. In the present age of growing technological, economic, cultural and social awareness, accounting does not only have to fulfill its stewardship function for the owners of the enterprise, but also accomplish its social function. Changing environments and social parameters have compelled business enterprises to account and report information with regard to discharge of their social responsibilities. The boundaries of the principles, practices and skills of conventional accounting have been extended to such areas for social disclosure and attestation with regard to the measures of social programs.

Global extended communication trends and regulations changes have influenced the concept at the international level and increased public awareness regarding social responsibility of companies started to develop during the late 50's and early 60's of the 20 ${ }^{\text {th }}$ century the stakeholders theory was born. Stakeholder theory was the dominant paradigm shift of SRA in the $20^{\text {th }}$ century during this decade corporate performance was closely linked to stakeholder satisfaction. Researchers identified the direction of future discussions and raised some questions about whether CSR yields profit. Wood (1991) introduced the social performance model and his main focus was results or performance. The late 1990's saw stakeholder activities related to social dimensions anchored on financial performance and related works. The results of this concept meant that good behavior and desirable manners is seen to reduce stakeholders' risks.

In the 1920's managers defined SRA using two basic criteria responsibility and responsible performance research (Windsor, 2001). While in the 1950's SRA was conceptualized as reflecting decisions and approaches that are desirable for society according to social values and goals (Bowen, 2013). This lead to Bowen being named the father of CSR as he began in 1953 to initiate a novel period of CSR and had a wide view of business responsibility that included stewardship, social auditory and corporate citizenship. By extension to the 60's disclosure had become the bane of SRA. Davis (1973) pointed that socially responsible decisions could be justified as a good chance to make long-term profit. He emphasized that resources must be used to increase social disclosure and not only to make profit for individuals and companies. After the 70's came a paradigm shift in CSR as described by Freeman, Wicks and Palmar (2004) as a period of a more responsible attitude toward corporate guidelines.

\section{Theoretical Framework}

CSR affirms that corporations are entities with economic legal ethical and philanthropic obligations and corporate ethics built on the stakeholders theory seek to involve all these affected by the organization in its decision making process. Thus this study is primarily anchored on the stakeholder theory.

\section{Stakeholder Theory}

The stakeholder theory which has been described by Freeman (1984) and others is the mirror image of corporate social responsibility. It lists and describes those individuals and groups who will be affected by (or affect) the company's actions and asks: What are their legitimate claims on the business? What right do they have with respect to the company's actions? What kind of responsibility and obligation can they justifiably impose on a particular business? In a single sentence, stakeholders' theory affirms that those whose lives are touched by a corporation hold a right and obligation to participate in directing the affairs of that business entity. 
Stakeholder theory suggest that companies are responsible not only to shareholders, but to a range of stakeholders such as shareholders, management, customers, suppliers, employees, trade union, lenders, members of the society or host communities, the investing public and government, all of which are impacted by a firm's activities (Freeman, Harrison \& Wicks 2007). This view was upheld by Eyre (1982) stating that there are a number of interested parties to be considered in the formulation of business objectives. These parties include shareholders, managers, employees, customers, suppliers and the host community. The basic proposition of the stakeholder theory is that the firm's success is dependent upon the successful management of all the relationship that a firm has with its stakeholders (Ezeagba, John-Akamelu \& Umeoduagu, 2017).

\section{Past Empirical literature}

\section{Empirical Studies in Europe and US}

Akisik and Gal (2011) examined the relationship of sustainable development in business with corporate social responsibility and accounting in 53 developed and emerging economies for the period covering 1917 to 2008 . The study employed ordinary least squares estimation techniques to analyze panel data obtained for the study. The results revealed that sustainable development was strongly related to CSR and accounting standards. They therefore concluded that socially responsible firms and good accounting standards are likely to contribute to sustainable development in business in developing and emerging markets. Giannarakis, Konteos, Zafeiriou and Partalidou (2016) investigated the effect of CSR on financial performance of companies listed on the Standard \& Poor's 500 Index in the US for the period 2009 to 2013. Data for the study was collected from a sample of 104 companies from the Bloomberg online database for voluntary disclosure. The study employed fixed effects regression estimation techniques for data analysis. The results indicated that CSR initiatives had significant positive effect on financial performance.

Charlo, Moya and Munoz (2017) conducted a cross-sectional and longitudinal survey to analyze the association between social performance and financial performance of Spanish listed firms. The Spanish Responsibility Index (FTSE4Good IBEX), a listing of socially responsible companies was published in 2008. The study covering the period 2008 to 2013 was aimed at examining the link between social performance and financial performance of the Spanish responsibility indexed companies and those not listed as socially responsible companies. The results of the survey revealed that socially responsible firms continue to voluntarily incorporate good corporate social responsibility practices into their business plans and policies than others; and such companies exhibit higher systematic risk and have larger firm size. However, being socially responsible does not mean better profits or business results, the study noted. Akben-Selcuk (2019) examined the impact of CSR practices on financial performance of 70 non-financial firms listed on the Borsa Istanbul 100 index in Turkey using secondary data for the period 2014 to 2018. The study employed descriptive statistics and pairwise correlation techniques for data analysis. The results showed that CSR practices had positive relationship with ROA, while ownership concentration was negatively related to ROA.

\section{Empirical Studies in Middle East}

Junejo, Gohar, Rochwani and Rubab (2018) investigated the association between internal CSR on employee job satisfaction in selected private schools in Hyderabad, Sindh region of Pakistan. The study adopted health and safety, disabled support and employee rights as independent variables, while job satisfaction was used as the dependent variable. They employed multiple regression 
Etale, L. M., \& Sawyerr, A. E. (2020) Social Responsibility Accounting And Profitability Of Dangote Cement PLC Listed in the NSE. Advances in Social Sciences Research Journal, 7(5) 323-337.

technique based on windows SPSS 21 version to analyze data obtained through the use of a structured questionnaire. The findings showed that the adopted internal CSR components had significant positive effect on job satisfaction. They concluded therefore that the adoption of internal CSR practices in private schools caused reduction in labor turnover and training cost. Abdullah (2018) investigated the effect of social and environmental accounting practices on profitability of companies located in Erbil, Kurdistan Region of Iraq using primary data obtained through the use of a questionnaire in the year 2017. The survey involved a sample of 50 manufacturing companies. Profitability measures considered include return on capital, net profit margin, DPS or EPS. The study made use of Pearson's chi-square test for the evaluation of data. It was found that no significant relationship existed between social and environmental accounting practices and profitability of companies in the Kurdistan Region due to little or no awareness on environmental responsibility reporting requirements being an LD economy.

Ahmad, Waseer, Hussain and Ammara (2018) investigated the relationship between environmental accounting and performance of 9 non-financial firms listed in Pakistan Stock Exchange for the period 2006 to 2016. Secondary data for the study was collected from financial reports of sampled companies across different industrial sectors. They employed random effect model regression analysis based on E-views 7 software, unit root test, and descriptive statistics as methods of data analysis. The results showed a significant positive association between environmental accounting and firm size (one of the proxies for performance); because larger firms had the resources to invest in social welfare practices than small firms. Karaja, Al Shikh and Mansour (2019) examined the impact of social responsibility accounting on financial performance of 61 service companies listed on Amman Stock Exchange in Jordan for the period 2012 to 2016 . The study adopted EPS and ROA as proxies for financial performance and the dependent variables, while environmental protection, community service, and human resources representing social responsibility accounting were used as the independent variables. Secondary data was collected from audited annual financial statements of sampled companies. The study employed multiple regression and Pearson's correlation techniques for data analysis. The results indicated that social responsibility accounting had statistically significant impact on financial performance.

\section{Empirical Studies in India and Far East}

Makori and Jagongo (2013) investigated the relationship between environmental accounting and profitability of companies listed in the Bombay Stock Exchange in India. Secondary data for the study variables was obtained from published financial statements of 14 randomly selected companies for the year 2007. Data collected was analyzed using multiple regression technique, and the results revealed mixed effects: environmental accounting was shown to have significant negative link with return on capital employed and EPS; and a significant positive relationship with net profit margin and DPS. Hilmi (2016) examined the effect of social performance and environmental performance on financial performance of companies listed on the Indonesian Sustainability Index for the period 2012 to 2013. Secondary data obtained through content analysis of the financial statements of sampled companies were analyzed using descriptive statistics and multiple regression technique. The study found that social performance and environmental performance had significant positive effect on financial performance

Maqbool \& Zameer (2018) examined the relationship between corporate social responsibility and financial performance in Indian, using secondary data collected from 28 commercial banks listed on 
the Bombay Stock Exchange for the period covering 2007 to 2016. They adopted descriptive statistics and correlation techniques for data analysis. The results indicated that CSR practices exerted positive impact on financial performance. They therefore made a recommendation for Indian banks to integrate CSR accounting practices into their business policies to be seen as socially responsible entities.

\section{Empirical Studies in the rest of Africa}

Elouidani and Zoubir (2015) examined the relationship between CSR and financial performance in Morocco using data obtained from a sample of 20 companies listed on the Securities Exchange of Casablanca for the period 2007 to 2010. They conducted regression analysis on secondary data collected on the study variables and found that CSR had significant negative impact on financial performance. Magara, Aming'a and Momanyi (2015) examined the effect of environmental accounting of financial performance of companies in Kisii County of Kenya for the period 2006 to 2011. The study made use of both primary data (obtained through a structured questionnaire) and secondary data (collected from the financial statements of 16 sampled companies). Data obtained for the study was analyzed using qualitative and quantitative techniques based on descriptive and inferential statistics. The results showed that environmental accounting had significant positive effect on financial performance.

Chepkwony, Kemboi and Mutai (2015) investigated the effect of internal CSR practices on employee job satisfaction in 17 commercial banks in Kenya for the year 2013. They adopted workplace health and safety, work life balance, pay and benefits, and equality and diversity as proxies for internal CSR practices which were regressed against job satisfaction (the response variable). The study employed descriptive statistics and multiple regression technique as tools for data analysis. Their findings provided evidence that internal CSR practices had positive significant effect on job satisfaction. Gworo (2016) examined the relationship between social responsibility accounting and profitability of 20 listed firms in Kenya for the period 2001 to 2015. Secondary data on the study variables (ROCE, EPS, NPM, DPS and social costs) were collected from the annual reports of the selected companies. The study employed descriptive statistics and multiple regression techniques to analyze data. The results showed that social responsibility accounting had significant relationship with the adopted financial performance indicators.

\section{Empirical Studies in Nigeria}

Umoren, Isiavwe-Ogbari and Atolabge (2016) examined the determinants of corporate social responsibility disclosure practices of listed companies in Nigeria. Secondary data for the study was collected from the financial reports of 45 sampled companies for the period 2013 to 2014 . The study employed descriptive statistics, correlation and regression techniques as tools for data analysis. The findings revealed that corporate social responsibility disclosure practices were influenced by the size of the firm and auditor type, but profitability had no effect on CSR. Agbiogwu, Ihendinihu and Okafor (2016) investigated the impact of environmental social cost on performance of manufacturing firms in Nigeria. Secondary data was collected from the annual reports of 10 sampled companies listed on the NSE for the year 2014. The regression results based on SPSS version 20 revealed that environmental social cost had significant effect on financial performance.

Ezeagba, John-Akamelu and Umeoduagu (2017) noted that the debate on corporate social responsibility practices has brought about the design of corporate performance indices in a greater 
Etale, L. M., \& Sawyerr, A. E. (2020) Social Responsibility Accounting And Profitability Of Dangote Cement PLC Listed in the NSE. Advances in Social Sciences Research Journal, 7(5) 323-337.

context under the subtle influence of social and environmental factors to develop a holistic view of a firm's performance. Thus, their study examined the link between financial performance and environmental accounting disclosures of food and beverage companies in Nigeria for the period 2006 to 2015. Secondary data on the study variables were obtained from the annual reports of selected companies. The methods employed for the analysis of data include Pearson's correlation and multiple regression techniques based on windows SPSS 20 version. The results showed a mixed effect; that environmental accounting disclosures had a significant association with return on equity; and a negative relationship with return on capital employed and net profit margin. Ohaka and Ogaluzor (2018) examined the effect of CSR accounting (represented by donations) on profitability of oil and gas companies in Nigeria for the year 2016. The researcher used cross sectional survey design to carry out the research. The population of the study was all the oil and gas companies in Nigeria. The study variables include donations (representing CSR accounting), ROA, ROE and NPM. Data collected was analyzed using simple regression analysis and partial correlation based on windows SPSS 21 version. The results of the study revealed donations (proxy for CSR accounting significantly affected ROA, ROE, and NPM. The study concluded that CSR accounting had a strong relationship with profitability.

Daferighe, Akpanuko and Offiong (2019) examined the relationship between social accounting and profitability of companies in Nigeria for the period 2009 to 2015.They adopted health related welfare cost representing social accounting practices as the independent variable, while return on equity, proxy for profitability was used as the dependent variable. Secondary data for the study were obtained from 15 selected oil and gas, manufacturing, and building and construction sector companies listed on the Nigerian Stock Exchange. The results of data analysis based on the use of descriptive statistics and multiple regression analysis revealed that health related welfare cost had no significant relationship with return on equity. The study concluded therefore that investment in social activities would not positively influence profitability.

\section{METHODOLOGY}

This section presents the methods and procedures adopted in carrying out this study. The methodology discussed here include, the research design, source of data, model specification and data analysis techniques.

\section{Research Design}

The type of research design adopted in this study is the export facto research design. The export facto research design is used became this type of research is one that takes place after the event or the fact had taken place; it ensures the reliability of data since the researchers lack the powers to manipulate the study data. Furthermore, the study adopted the case study approach as Dangote Cement PLC (DCP), a major producer and marketer of cement in Africa and a company listed on the Nigerian Stock Exchange was conveniently sampled in focus.

\section{Source of Data}

This case study of DCP examined social responsibility accounting and profitability using profit after tax (proxy for profitability or performance) as the response variable, while staff training and development cost, staff welfare and healthcare cost and staff pension and gratuity (three components of social cost) were adopted as the explanatory variables. Secondary data for these variables were collected from the annual financial statements of DCP for the period covering 2010 
to 2018. The annual reports were downloaded from the company's website, and the number of years covered in the study was influenced by the ready availability of the required information.

\section{Model Specification}

To facilitate the analysis of data, the study adopted the following model which has been widely used by previous researchers such as Akisik and Gal (2011), Giannarakis et al (2016), and Akben-Selcuk (2019) to mention a few:

$$
P A T=f(T A D, W H C, P E N)
$$

The above model was translated into a regression equation as follows;

$$
P A T=\alpha+\beta_{1} T A D+\beta_{2} W H C+\beta_{3} P E N+e \quad \text { Equation } 1
$$

Where,

$P A T=$ Profit after tax, proxy for profitability, the response variable.

$T A D=$ Staff training and development cost a component of social cost.

$W H C=$ Staff welfare (including meal subsidies and canteen cost), and healthcare and safety cost. $\alpha=$ is the intercept or constant

$\beta_{1}$ to $\beta_{3}=$ are the coefficients of the explanatory variables to be determined, which defined the extent of the relationship between the response variable and the explanatory variables.

$e=$ is the error term of the equation.

\section{Data Analysis Techniques}

The study used descriptive statistics and multiple regression analysis based on the E-view 10 software, following the above model, as the techniques for data analysis. This technique is efficient and consistent and possesses the unique properties of best linear estimator compared to other estimation techniques.

\section{Presentation of Data}

\section{RESULTS OF DATA ANALYSIS AND DISCUSSION OF FINDINGS}

Annual data for the study variables generated through content analysis of Dangote Cement PLC's (DCP) annual reports are presented in Table 1. The data represent annual figures for the variables computed from the company's annual reports, adopted for the study for the nine years period 2010 to 2018 .

Table 1: Annual Values of the Study Variables

\begin{tabular}{|c|c|c|c|c|}
\hline \multirow{2}{*}{ YEAR } & \multicolumn{2}{|c|}{ DEPENDENT VARIABLE } & \multicolumn{2}{c|}{ INDEPENDENT VARIABLES } \\
\cline { 2 - 5 } & PAT & TAD & WHC & PEN \\
\hline $\mathbf{2 0 1 0}$ & 7.40 & 6.40 & 12.20 & 61.40 \\
\hline $\mathbf{2 0 1 1}$ & 10.80 & 8.80 & 18.50 & 68.70 \\
\hline $\mathbf{2 0 1 2}$ & 11.30 & 10.10 & 26.30 & 89.70 \\
\hline $\mathbf{2 0 1 3}$ & 11.90 & 10.50 & 32.10 & 93.40 \\
\hline $\mathbf{2 0 1 4}$ & 12.70 & 12.00 & 36.90 & 126.20 \\
\hline $\mathbf{2 0 1 5}$ & 13.50 & 13.70 & 37.20 & 137.10 \\
\hline $\mathbf{2 0 1 6}$ & 14.20 & 14.00 & 41.60 & 151.90 \\
\hline $\mathbf{2 0 1 7}$ & 25.80 & 34.00 & 72.70 & 175.00 \\
\hline $\mathbf{2 0 1 8}$ & 37.80 & 38.20 & 190.90 & 223.90 \\
\hline
\end{tabular}

Source: Researchers' computation from Annual Reports of DCP 
Etale, L. M., \& Sawyerr, A. E. (2020) Social Responsibility Accounting And Profitability Of Dangote Cement PLC Listed in the NSE. Advances in Social Sciences Research Journal, 7(5) 323-337.

\section{Descriptive Statistics}

\section{RESULTS OF DATA ANALYSIS}

The summary of the descriptive statistics of the variables is shown in Table 2. Table 2 shows that PAT, TAD, WHC and PEN have mean of 16.16, 16.41, 52.04 and 125.26 respectively. On the other hand, the maximum values of PAT, TAD, WHC and PEN are 37.80, 38.20, 190.90 and 223.90 respectively. While there minimum values are $7.40,6.40,12.20$ and 61.40 respectively.

Table 2 further shows that the standard deviation of PAT, TAD, WHC and PEN are 9.56, 11.45, 54.82 and 53.16 respectively. The indication is that WHC is the most dispersed variable among the variables in the study, while PAT is the least dispersed among the variables. The Jarque-Bera statistics and the associated probability values also shows that PAT, TAD and PEN are normally distributed with probabilities of 0.152, 0.327, and 0.748 (which are greater than 5 per cent), respectively. WHC with probability value of 0.009 which is less than 0.05 is not normally distributed, though this has no effect on the results as the overall probability (F-statistics) value of 0.000000 shows that the regression model is significantly strong.

\section{Discussion of Findings}

Table 3 shows the results of the multiple regression analysis. From Table 3 , the regression equation 1 can be restated as follows:

$$
\mathrm{PAT}=4.53+0.46 \mathrm{TAD}+0.09 \mathrm{WHC}-0.003 \mathrm{PEN}+0.58 \quad \text { Equation } 2
$$

Equation 2 shows the extent of the association between the response variable PAT and the explanatory variables TAD, WHC and PEN. Equation was also used along Table 3 to test the hypotheses of the study. Furthermore from the results as shown in Table 3, the explanatory variables combined significantly explained changes in the response variable with probability of Fstatistic value of 0.000000 (at 5\% level of significance). Secondly, the coefficient of determination (R-squared) value of 0.997735 indicates that $99 \%$ of changes in the response variable are accounted for by the combined effect of variations in the explanatory variables. Also, the adjusted R- squared value of 0.996376 indicates that the model used is a proper and good fit for testing the hypotheses of the study. This provides a high confidence level (at approximately $99 \%$ for acceptance of the goodness of the study model. 
Table 2: Descriptive Statistics

\begin{tabular}{|c|c|c|c|c|}
\hline & PAT & TAD & WHC & PEN \\
\hline Mean & 16.15556 & 16.41111 & 52.04444 & 125.2556 \\
\hline Median & 12.70000 & 12.00000 & 36.90000 & 126.2000 \\
\hline Maximum & 37.80000 & 38.20000 & 190.9000 & 223.9000 \\
\hline Minimum & 7.400000 & 6.400000 & 12.20000 & 61.40000 \\
\hline Std. Dev. & 9.561264 & 11.45463 & 54.81752 & 53.16411 \\
\hline Skewness & 1.509757 & 1.214186 & 2.054190 & 0.516171 \\
\hline Kurtosis & 3.969731 & 2.759096 & 5.862331 & 2.302811 \\
\hline Jarque-Bera & 3.771693 & 2.233133 & 9.401895 & 0.581927 \\
\hline Probability & 0.151701 & 0.327402 & 0.009087 & 0.747543 \\
\hline Sum & 145.4000 & 147.7000 & 468.4000 & 1127.300 \\
\hline Sum Sq. Dev. & 731.3422 & 1049.669 & 24039.68 & 22611.38 \\
\hline Observations & 9 & 9 & 9 & 9 \\
\hline
\end{tabular}

Source: E-views 10 output

\section{Regression Results}

Table 3: Multiple Regression Results

\begin{tabular}{|c|c|c|c|c|}
\hline \multicolumn{5}{|c|}{ Dependent Variable: PAT } \\
\hline \multicolumn{5}{|c|}{ Dethod: Least Squares } \\
\hline \multicolumn{5}{|c|}{ Sample: 20102018} \\
\hline \multicolumn{5}{|c|}{ Included observations: 9} \\
\hline Variable & Coefficient & Std. Error & t-Statistic & Prob. \\
\hline C & 4.530505 & 0.697976 & 6.490916 & 0.0013 \\
\hline TAD & 0.460989 & 0.047467 & 9.711858 & 0.0002 \\
\hline WHC & 0.086070 & 0.008536 & 10.08270 & 0.0002 \\
\hline PEN & -0.003351 & 0.009527 & -0.351737 & 0.7394 \\
\hline R-squared & 0.997735 & Mean dependent var. & 16.15556 \\
\hline Adjusted R-squared & 0.996376 & S.D. dependent var. & 9.561264 \\
\hline S.E. of regression & 0.575585 & Akaike info criterion & 2.034242 \\
\hline Sum squared resid & 1.656490 & Schwarz criterion & 2.121898 \\
\hline F-statistic & 734.1686 & Hannan-Quinn criter. & 1.845082 \\
\hline Prob.(F-statistic) & 0.000000 & Durbin-Watson stat & 2.289645 \\
\hline
\end{tabular}

Source: E-views 10 Output

Furthermore, the Durbin- Watson statistics value of 2.289645 is approximately equal to the 2.0 benchmark, which indicates the non-existence of serial auto correlation among the independent variables. 
Etale, L. M., \& Sawyerr, A. E. (2020) Social Responsibility Accounting And Profitability Of Dangote Cement PLC Listed in the NSE. Advances in Social Sciences Research Journal, 7(5) 323-337.

Overall, the regression results used to verify the relationship between social responsibility accounting, (TAD, WHC and PEN) and profitability (PAT) indicated strong significant relationship between the explanatory variables and response variable going by the probability of F-statistic value. Overall the regression results showed that social responsibility accounting has a statistically significant relationship with profitability. The findings of this study are in agreement with the study findings of Akben-Selcuk (2019) and Karaja, Al Shikh and Mansour (2019), but contradicted the findings of Daferighe, et al (2019). This is quite understandable because this study used data from a single company as a case study.

\section{Test of hypotheses}

The calculated values of the co-efficient of the explanatory variables were used in testing the study hypotheses in the following sections.

\section{Staff training and development cost (TAD) and Profit after Tax (PAT)}

There is no significant relationship between TAD and PAT. From Table 3, the coefficient of TAD is 0.460989 with a P-value of 0.0002 . This means that TAD has a positive significant relationship with PAT (significant at 5\% level). Therefore, the null hypothesis is rejected. The implication is that a unit change in TAD will lead to 0.46 unit change in PAT.

\section{Staff welfare and healthcare cost (WHC) and Profit after Tax (PAT)}

There is no significant relationship between WHC and PAT. Again, from Table 3 the coefficient of WHC is 0.086070 with P-value of 0.0002 . This means WHC has positive significant relationship with PAT; this is statistically significant at $5 \%$ level. So the null hypothesis is rejected. The economic implication being that a unit change in WHC will bring about 0.086 units change in PAT.

\section{Staff pension and gratuity (PEN) and Profit after Tax (PAT)}

There is no significant relationship between PEN and PAT. Again, from Table 3 the coefficient of PEN is -0.003351 with P-value of 0.7394. This means PEN has an insignificant negative relationship with PAT. In this case the null hypothesis is accepted: that there is no significant relationship between PEN and PAT. However, this finding also mean that a little increase in PAT would be expected from a slight drop in PEN.

\section{Summary}

\section{SUMMARY, CONCLUSION AND RECOMMENDATIONS}

This study examined the relationship between social responsibility accounting and profitability using Dangote Cement PLC (DCP) as a case study. Staff training and development cost (TAD), staff welfare and healthcare costs (WHC) and staff pension and gratuity (PEN), were used to represent social responsibility accounting (the explanatory variables); while profit after tax (PAT) was used as proxy for profitability (the response variable). The findings of the study are summarized as follows:

1. Staff training and development cost (TAD) had positive statistically significant link with profit after tax (PAT) with p-value of 0.0002 and co-efficient of determination of about 0.46.

2. Staff welfare and healthcare cost (WHC) had positive significant relationship with profit after tax (PAT), with p-value of 0.0002 and co-efficient of determination of 0.086 . 
3. Staff pension and gratuity (PEN) had a negative insignificant association with profit after tax (PAT) with p-value of 0.7394 and co-efficient of determination of -0.003351 .

\section{Conclusion}

This study examined the relationship between social responsibility accounting and profitability with a focus on Dangote Cement PLC (DCP) in a case study. The study adopted staff training and development (TAD), staff welfare and healthcare cost (WHC) and staff pension and gratuity (PEN) as proxy for social responsibility accounting (the explanatory variables), while profit after tax (PAT) representing profitability was adopted as the response variable. Secondary data for the selected study variables were obtained from the annual financial statements of DCP for the period 2010 to 2018. The study employed descriptive statistics and multiple regression analysis based on the Eview 10 software as techniques for data analysis. The results revealed that staff training and development, and staff welfare and healthcare cost had significant positive relationship with profit after tax, while staff pension and gratuity had an insignificant negative link with profit after tax. The regression results also showed that the coefficient of determination (R-squared) value of approximately 0.99 indicating that $99 \%$ of changes in the response variable are accounted for by the combined effect of changes in the explanatory variables. The combined effect of variations of the explanatory variables significantly explained changes in the response variable with probability of F-statistic value of 0.000000 (at $5 \%$ level of significance). Furthermore, the adjusted R- squared value of 0.99 indicates that the model used for the analysis is a proper and good fit. The study concluded that social responsibility accounting is significantly related to profitability.

\section{Recommendations}

Based on the findings of this study it is recommended that the management of Dangote Cement PLC should continue to implement the social responsibility accounting policies already put in place as these provide a good social image for the company. The positive assessment of DCP by society would guarantee the long run sustainable growth of the company.

\section{References}

Abdullah, A. S. (2018) Social and environmental accounting effect on companies' profit (An empirical study of some companies in Erbil), Accounting and Financial Management Journal, 3(7), 1621-1633

Agbiogwu, A. A., Ihendinihu, J. U. \& Okafor, M. C. (2016) Impact of environmental accounting and social costs on performance of Nigerian manufacturing companies, International Journal of Economics and Finance, 8(9), 173-180

Ahmad, M., Waseer, W. A., Hussain, S. \& Ammara, U. (2018) Relationship between environmental accounting and nonfinancial firms performance: An empirical analysis of selected firms listed in Pakistan Stock Exchange, Pakistan, Advances in Social Sciences Research Journal, 5(1), 197-209

Akben-Selcuk, E. (2019) Corporate social responsibility and financial performance: The moderating role of ownership concentration in Turkey, Sustainability, 11(3643), 1-10

Akisik, O. \& Gal, G. (2011) Sustainability in business, corporate social responsibility, and accounting standards: An empirical study, International Journal of Accounting and Information Management, 19(3), 304-324

Arenas, D., Lozano, J. M. \& Albareda, L. (2009) The role of NGOs in CSR: Mutual perceptions among stakeholders, Journal of Business Ethics, 88(1), 175-197

Atu, O. O. K (2013) Triple bottom line accounting; A conceptual expose, IOSR Journal of Business and Management, 13(4), 30-36

Bowen, H. R. (2013) Social Responsibility of the Businessman, 2013 Edition, University of Iowa Press, Iowa 
Etale, L. M., \& Sawyerr, A. E. (2020) Social Responsibility Accounting And Profitability Of Dangote Cement PLC Listed in the NSE. Advances in Social Sciences Research Journal, 7(5) 323-337.

Charlo, M. T., Moya, I. \& Munoz, A. M. (2017) Financial performance of socially responsible firms: The short- and longterm impact, Sustainability, MDPI, 9(1622), 1-15

Chepkwony, P., Kemboi, A. \& Mutai, S. K. (2015) Effects of internal corporate social responsibility practices on employee job satisfaction: Evidence from commercial banks in Kenya, International Journal of Business and Management Review, 3(1), 24-40

Daferighe, E. E., Akpanuko, E. E. \& Offiong, P. E. (2019) Social accounting practices and profitability of companies in Nigeria, Archives of Business Research, 7(5), 233-246

Davis, K. (1973) The case for and against business assumption of social responsibilities, The Academy of Management Journal, 16(2), 312-322

Elkington, J. (1997) Cannibals with Forks: The Triple Bottom Line of 21sth Century Business, Capstone, Oxford Elouidani, A. \& Zoubir, F. (2015) Corporate social responsibility and financial performance, African Journal of Accounting, Auditing and Finance, 4(1), 74-85

Eyre, E. C. (1982) Mastering Basic Management, Macmillan Press, Hong Kong

Ezeagba, C. E., John-Akamelu, C. R. \& Umeoduagu, C. (2017) Environmental accounting disclosures and financial performance: A study of selected food and beverage companies in Nigeria (2006-2015), International Journal of Academic Research in Business and Social Sciences, 7(9), 162-174

Freeman, R. E. (1984) Strategic Management: A Stakeholders Approach, Pitman Publishing Inc., Boston

Freeman, R. E., Harrison, J. S. \& Wicks, A. C. (2007) Managing for Stakeholders: Survival, Reputation and Success, Yale University Press, New Haven

Freeman, R. E., Wicks, A. C. \& Parmar, B. L. (2004) Stakeholder theory and the corporate objective revisited, Organization Science, 15(3), 364-369

Giannarakis, G., Konteos, G., Zafeiriou, E. \& Partalidou, X. (2016) The impact of corporate social responsibility on financial performance, Investment, Management and Financial Innovations, 13(3), 171-182

Gworo, C. (2016) Impact of social responsibility accounting on the future profitability of listed firms in Kenya, International Journal of Current Research, 8(11), 41375-41380)

Helg, A. (2007) Corporate social responsibility from a Nigerian perspective, Unpublished Master Thesis at Stockholm School of Economics, Handelshogskolan Stockholm, Sweden, 1-101 www.cor.ac.uk Accessed 27/04/2020

Hilmi (2016) Effect of social and environmental performance on financial performance of the company, European Journal of Accounting, Auditing and Finance Research, 4(9), 30-59

Junejo, I., Gohar, F., Rochwani, L. \& Rubab, N. (2018) Impact of internal corporate social responsibility on faculty job satisfaction in selected private schools in Hyderabad, Sindh, Pakistan, International Journal of Entrepreneurial Research, 1(1), 7-10

Karaja, A., Al Shikh, E. \& Mansour, I. (2019) Impact of applying social responsibility accounting on companies' financial performance, European Journal of Business and Management, 11(15), 144-154

Magara, R., Aming'a, N. N. \& Momanyi, E. (2015) Effect of environmental accounting on company financial performance in Kisii County, British Journal of Economics, Management \& Trade, 10(1), 1-11

Makori, D. M. \& Jagongo, A. (2013) Environmental accounting and firm profitability: An empirical analysis of selected firms listed in Bombay Stock Exchange, India, International Journal of Humanities and Social Science, 3(18), 248-256

Maqbool, S. \& Zameer, M. N. (2018) Corporate social responsibility and financial performance: An empirical analysis of Indian banks, Future Business Journal, 4(2018), 84-93

Ohaka, J. \& Ogaluzor, O. I. (2018) Corporate social responsibility accounting and the effect of donations on profitability of oil and gas companies in Nigeria, International Journal of Academic Research in Accounting, Finance and

Management Sciences, 8(3), 265-276 
Umoren, A. O., Isiavwe-Ogbari, M. E. \& Atolagbe, T. M. (2016) Corporate social responsibility and firm performance: A study of listed firms in Nigeria, A Paper Presented at ICAN Second International Academic Conference on Accounting and Finance at Lagos Airport Hotel, Ikeja, May 18-20, 983-998

Vives, A. (2006) Social and environmental responsibility in small and medium enterprises in Latin America, The Journal of Corporate Citizenship, 21(Spring 2006), 39-50

Wilson, M. \& Lombardi, R. (2001) Globalization and its discontents: The arrival of triple bottom line reporting, Ivey Business Journal, 66(1), 69-72

Windsor, D. (2001) The future of corporate social responsibility, International Journal of Organizational Analysis, 9(3), 225-256

Wood, D. J. (1991) Corporate social performance revisited, The Academy of Management Review, 16(4), 691-718

World Bank Institute (2003) Public Policy for Corporate Social Responsibility, (Ed.) Petkoski, D. \& Twose, N., Conference Report, July 7-25 